\title{
Praxis, Pedagogy and Teachers' Professionalism in England
}

ANDREA RAIKER ${ }^{1}$

$\approx$ The article considers current teachers' participation in educational research in England and whether Stenhouse's perception that such involvement was necessary to stall the political undermining of democratic teacher professionalism has been addressed. Stenhouse instigated the emergence of the teacher-as-researcher movement, whereby teachers engaged with a process that created knowledge and practice. From 1979, when the Conservative Margaret Thatcher became Prime Minister, the increasing dominance of globalised knowledge economies turned knowledge away from being a process into a product. Teacher and student education became controlled and consumed by increasingly competitive educational institutions. Learning became aimed at assuring the attainment of higher grades to increase the country's economic growth and profit, leading to democratic teacher professionalism being undermined. However, contemporary research by the Organisation for Economic Cooperation and Development has indicated that teacher professionalism should involve teachers in conducting classroom-based individual or collaborative research. In addition, a recent academic inquiry by the British Education Research Association has concluded that teachers as researchers, in both literate and practical terms, will have a positive impact on learner outcomes by developing an education system that has the internal capacity to direct its own progress. At the same time, the Department for Education in England commissioned a two-year study to assess progress towards an evidence-informed teaching system. Taking a systematic literature approach, the present article considers the extent to which current teacher education and practice encourage teacher research as a form of developing pedagogical practice, in other words, praxis, in order to re-establish democratic teacher professionalism in England. It also explores whether there are alternative practices to create the same, or a similar, outcome.

Keywords: pedagogy, praxis, professionalism, critical reflection, research 


\title{
Praksa, pedagogika in učiteljska strokovnost v Angliji
}

\author{
Andrea Raiker
}

$\propto$ Prispevek obravnava trenutno udeležbo učiteljev pri raziskovanju izobraževanja v Angliji in preverja, ali je bilo naslovljeno Stenhousovo dojemanje, da je takšna vpletenost nujna za zadrževanje političnega spodkopavanja demokratične učiteljske strokovnosti. Stenhouse je sprožil nastanek gibanja učitelja kot raziskovalca, s čimer so se učitelji vklopili v proces, ki je ustvaril znanje in prakso. Od leta 1979, ko je konservativka Margaret Thatcher postala premierka, je naraščajoča prevlada globaliziranih ekonomij znanja znanje preusmerila od procesa $\mathrm{k}$ produktu. Izobraževanje učiteljev in študentov je postalo nadzorovano in prežeto s strani čedalje konkurenčnejših izobraževalnih ustanov. Cilj znanja je bil zagotoviti doseganje višjih ocen, s katerimi bi se povečala gospodarska rast in dobiček države, kar pa je vodilo v spodkopavanje demokratične učiteljske strokovnosti. Aktualne raziskave Organizacije za gospodarsko sodelovanje in razvoj pa kažejo, da bi morala učiteljeva strokovnost vključevati učitelje v izvajanje individualnih ali skupnih raziskav v učilnici. Poleg tega je nedavna akademska preiskava Britanskega združenja za raziskovanje izobraževanja (angl. British Education Research Association) ugotovila, da bodo učitelji kot raziskovalci v teoretičnem in praktičnem smislu pozitivno vplivali na rezultate učenja $\mathrm{Z}$ razvojem izobraževalnega sistema, ki ima notranjo zmožnost po usmerjanju lastnega napredka. Hkrati je angleško ministrstvo za izobraževanje naročilo dveletno raziskavo, s katero bodo ocenili napredek v sistemu, ki bi temeljil na informiranju o izsledkih. Prek sistematičnega pregleda literature prispevek obravnava, kako trenutno izobraževanje učiteljev in praksa spodbujata učiteljevo raziskovalno dejavnost kot obliko razvoja pedagoške prakse zaradi ponovne vzpostavitve demokratične učiteljske strokovnosti. Raziskuje tudi, ali obstajajo alternative poti za ustvarjanje enakega ali podobnega rezultata.

Ključne besede: pedagogika, praksa, strokovnost, kritična refleksija, raziskovanje 


\section{Introduction}

Teacher professionalism is defined by the Organisation for Economic Cooperation and Development (OECD) as the knowledge, skills and practices that teachers must have in order to be educators. This definition is based on a survey of teachers and principals in 34 countries and economies around the world carried out in 2012. Details of the survey's data collection and analysis were presented in the Teaching and Learning International Survey (TALIS, 2016), along with its findings on teacher professionalism. A crucial conclusion is that in order for this definition to be achieved, knowledge bases containing the necessary knowledge for teaching (including pre-service and in-service training) should involve autonomy in practitioners' work decision-making. Another significant conclusion is that in order to maintain high standards of teaching, engagement in peer networks is needed so as to provide opportunities for information exchange and support.

Some years ago, in their work integrating Habermas's (1986) conceptions of communicative action with school teacher education, Carr and Kemmis (1986, p. 221) proposed that schoolteachers could "organise themselves as communities of enquirers, organising their own enlightenment". This reflects the OECD's identification of engagement in peer networks, but for something more than just information exchange and support. Enlightenment involves insight, the result of personal and purposeful critical reflection and evaluation. This resonates with research, but relates to problem-solving based on personal experience. Experience can occur haphazardly for individuals; research is based on systematic and controlled data collection, analysis and evaluation that can be open to scrutiny by fellow professionals. Research is not a technical exercise. As Cohen, Manion and Morrison (2005, p. 3) point out in their consideration of educational research, "research is concerned with understanding the world and that is informed by how we view our world(s), what we take understanding to be, and what we see as the purposes of understanding". In other words, collecting empirical data through observation, interview and questionnaires provides a certain practical level of research, structuring it with growing ontological, epistemological and theoretic awareness and understanding results in higher levels of research. This consideration therefore suggests that teacher professionalism should include research that can be done with others but requires an individual awareness and understanding of theory. The OECD acknowledged this in proposing that education policies should consider "supporting teachers in conducting classroom-based individual or collaborative research" (2016, p. 23) in order for this conceptualisation to be achieved. 
Awareness and understanding of theory, resulting in particular practice in teaching and learning, also leads to increased mindfulness and perception of pedagogy. However, for many years in the past in England and in Britain as a whole, there has been little academic critical thought regarding the meaning of "pedagogy". As Simon concludes, "dominant educational institutions... have had no concern with theory, its relation to practice with pedagogy" (1981, p. 11). Simon believes that this was because since the nineteenth century, schools have believed that education should be concerned with "character" rather than intellect. Kemmis saw this as producing a technical view of teachers' identities and their teaching, which demeans their practice:

... a long tradition of splitting facts and values in positivistic science and pseudo-science...threatens to empty practice of its moral dimension. This is a price the professional practitioner should not be prepared to pay for the 'certainties' allegedly given by the particularly restricted range of 'evidence' that 'counts' in the evidence-based approach to practice. Practice is just not that simple. (2010, p. 160)

Kemmis goes on to argue strongly and persuasively that the conception of teachers as subject experts and pedagogical technicians should be extended to include conceptions of teachers as being socially, discursively, culturally and historically formed. Through conducting their own research, not only will teachers become more knowledgeable and have a greater understanding of the what, why and how of teaching, they will also know and understand more of the what, why and how of students' learning and how ideologies impact on these. What is more, they will have a greater understanding of the social, discursive, cultural and historical dimensions that have resulted in the current education policy and practice, and will gain the knowledge and evaluative skills to question these dimensions. When Simon was writing in the 1980s, pedagogy in the UK was considered to be didactic, a science of teaching knowledge and understanding of prescriptive content. The present article begins by evaluating whether faculties of education have introduced their students - or trainees as they have been called for decades - to a new epistemology of practice in which the notion of praxis is central. Praxis relates theory to practice, resulting in pedagogies that can be justified by autonomous reflection, not by conforming to external demands. This can lead to a profound change in teachers' understanding of their professional identity, giving them the power to democratise their profession further through taking control, as Lawrence Stenhouse advised and contended. Clearly research impacts on praxis. 
In 2014, the British Education Research Association (BERA) published its final report on Research and the Teaching Profession: Building the Capacity for a Self-Improving Education System. The report states "The evidence gathered by the inquiry is clear about the positive impact that a research literate and research engaged profession is likely to have on learners' outcomes" (2014, p. 6). The report also calls for "commissioners of education research [to] build teacher engagement into commissioning processes, so that whenever possible teachers are involved in the democratic process of being active agents in research, rather than passive participants" (ibid. 8). This makes a strong case for schools and colleges to become research-rich environments and for teachers to be research literate. The report calls on "policymakers" to follow the Scottish model in which research is embedded within career-long professional learning, and for universities and others to reach out and support those who are engaging in practitioner research to inform strategic improvement.

Coincidently, in August 2014, the Department for Education (DfE) commissioned a two-year study to assess progress towards an evidence-informed teaching system. In the resulting report, published in 2017 as Evidence-informed teaching: an evaluation of progress in England, the term "evidence-informed teaching" is used to mean practice that is influenced by robust research evidence. However, a key finding of this research is that:

Most teachers interviewed did not feel confident in engaging with research directly, or feel able to judge its quality, relying on senior leaders and other organisations like the Sutton Trust and the Education Endowment Foundation (EEF). The exceptions were those undertaking higher level academic study. (2017, pp. 6-7)

This key finding has generated the purpose of the present article: to assess the importance of research in teacher education as necessary in order for teachers to know about and understand pedagogy and praxis so as to maintain and develop high quality teacher professionalism. The article begins by considering whether current teacher education in England encourages teacher research as a form of developing pedagogical practice. It then considers the political context of teacher research since the 1960s, and the recent rise of critical reflection in teacher education and its relation to pedagogical practice. It concludes with an assessment of contemporary praxis, pedagogy and professionalism in England in relation to the OECD, BERA and DfE conclusions. 


\section{Pedagogy, research and teacher education in England}

As the OECD advocates in TALIS (2016, p. 23), Britain meets the requirement for "teachers to participate in pre-service formal teacher education programmes". This requirement continues in stating that education programmes must "expose teachers to pedagogy and provide opportunities for practice teaching". In England, however, there are problems in educating teachers to be pedagogically informed. Since the 1963 Robbins Report on Higher Education, would-be teachers have entered universities to become qualified with Bachelor of Education degrees (CHE, 1963). For students who already have a degree, they enrol as trainees in a one-year Postgraduate Certificate of Education (PGCE) in either primary or secondary education (Hopkins, 2020). These courses have seminars and lectures on educational theory, policy and pedagogy, but usually only on brief occasions during the one day a week the students spend in their universities during term time; the rest of the week is spent in a series of placements in local schools. Clearly, these trainees do not have much time to learn about educational theory and research. Yet, if successful in their studies and school practice, they will be awarded Qualified Teacher Status (QTS). Students are also able to gain QTS by training as primary teachers at undergraduate level by doing a three-year BA (Hons) in Primary Education. However, whatever the course in non-Russell Group universities (24 research-intensive world-class UK universities), entry qualifications are based on moderate, even low, grades. Currently, such universities are being criticised for making "conditional unconditional" offers to applicants. Although these offers are initially conditional on A-level results (final examinations in secondary schools), they become unconditional if the applicant makes that university their first choice, meaning that s/he does not need to achieve the stated A-level grades (UCAS, 2019). In education faculties, it is difficult for an applicant not to be awarded a place, as there is a shortage of teachers in the UK and the number of pupils is rising (Sibieta, 2020). Therefore, a key aim of education faculties is for trainees to pass. Although there is some time for trainees to learn about educational theory and research for their dissertations, not all trainees will want to do so, nor will they all have the necessary time or regard it as essential to engage with theoretic thought.

There have been and still are concerns raised in certain pre- and postsecondary education institutions that university-based teacher education relies on lecturers who do not have day-to-day connections with schools and colleges (Raiker, 2010b). This results in university lecturers not being sufficiently knowledgeable about what constitutes actually being a teacher in schools, which vary so much in England depending on their location, demographics, 
lowering finance and changing policy. Together with concerns about university-educated teacher quality, this resulted in the Labour government moving teacher education into schools through "school-centred initial teacher training" (usually referred to as SCITT) when coming into power in 1997 (Hopkins, 2020). SCITTs consist of a coalition of local schools that sometimes have a relationship with a university, but often do not. Either way, they are able to train teachers and award QTS if their students are successful in completing their programmes. There are now other ways of acquiring QTS, as well. For example, the programme School Direct is apprentice-type training whereby schools employ and pay unqualified persons with the aim of awarding them with QTS and employing them if they are successful. Another option is Teach First, whereby highly qualified graduates, including those with master's degrees and $\mathrm{PhDs}$, are employed after some initial training and supported by mentors in city schools situated in low socioeconomic locations. With little time spent in education faculties, it is difficult for these trainees to acquire an understanding of pedagogy and to engage with praxis.

The lack of knowledge and understanding of educational theory and research practice does not impact greatly on trainees' potential to gain QTS. The role of the teacher in England is determined by the Teachers' Standards (DfE, 2012), which define the minimum level of specified competences to be achieved to be awarded QTS, a benchmark that can be subsequently used for future continuing professional development (CPD) and teacher professionalism. The eight teaching standards and three statements defining personal and professional conduct, examined in practice by the government's Office of Standards in Education (OfSTED), are given in Table 1 below:

Table 1

The role of the teacher

\footnotetext{
PART 1 Teaching; a teacher must:

- set high expectations which inspire, motivate and challenge pupils;

- promote good progress and outcomes of pupils;

- demonstrate good subject and curriculum knowledge;

- plan and teach well-structured lessons;

- adapt teaching to respond to the strengths and need of all pupils;

- make accurate and productive use of assessment;

- manage behaviour effectively to ensure a good and safe learning environment;

- fulfil wider professional responsibilities.
} 


\section{PART 2 Personal and professional conduct: \\ - teachers uphold public trust in the profession and maintain high standards of ethics and behaviour, within and outside school; \\ - teachers must have proper and professional regard for the ethos, policies and practices of the school in which they teach, and maintain high standards in their own attendance and punctuality; \\ - teachers must have an understanding of, and always act within, the statutory frame- works which set out their professional duties and responsibilities.}

Note. Adapted from Teachers' Standards, 2012.

In the past two decades, however, schools in the compulsory state sector have been given the option of leaving local authority control and their budgets to become "academies", which gain their finances directly from the DfE (thus being directly under its control) and can choose their own balanced and broadly based curriculum on the basis of the 2002 Education Act (DfE, 2002). Furthermore, academies and "free schools" - educational institutions established on the initiative of parents, teachers, businesses or organisations in the local community (subject to approval by the Secretary of State for Education) - do not have to employ teachers with QTS status, although they do have to conform to OfSTED criteria, which are based on the Teachers Standards. As can be seen, the words "research", "pedagogy", "educational theory" and "praxis" do not appear in the Teachers' Standards. The word "professional" does, however, appear several times, including in the title of Part 2. It is clear that the pedagogical approach of teachers in England, controlled by OfSTED, is expected to comply with political thinking and thus be didactic. This defines current teacher professionalism and explains its relationship to research. The conclusions of the OECD and BERA that research should be integrated into teaching practice and CPD are clearly not being implemented; nor is the DfE's conclusion that practice should be supported by robust research evidence: its research report states that "For teachers, evidence-informed teaching usually meant drawing on research evidence (directly or as translated by school leaders) to integrate and trial in their own practice, rather than directly applying research findings" (2017, p. 6). The impact of this on student attainment will be considered below. However, this has not always been the case, and change might be forthcoming. As the next section indicates, in England, Kemmis's conception of teachers being subject experts and pedagogical technicians should be extended to include conceptions of them being socially, discursively, culturally and historically formed, and to take into account the political determination of the time. 


\section{The political context of teacher research in England}

In the 1960 s, teacher professionalism became graduate education with dissertations involving research that included courses on philosophy. The $1960 \mathrm{~s}$ were a period of experimentation, with Local Education Authorities working with universities and schools. An example is the Secondary Humanities Curriculum project (Bramwell, 1976), aspects of which are still in evidence today in the form of dialogic teaching and the use of philosophy for children to explore problematic social and emotional issues. These progressive educational practices gave children a great deal of choice and freedom over what and when they learnt in school. Teachers had the choice and freedom to teach what they wanted to teach in a manner and to a timescale that suited them. Choice and freedom, i.e., autonomy, are key aspects of democracy. This prompted the emergence of the "teacher as researcher" movement, partly because teachers had the time and opportunities to carry out research, and partly because educationalists such as Lawrence Stenhouse and John Elliot rightly perceived the signs of a political reaction to the progressive educational practices that threatened democratic teacher professionalism. Progressive education had powerful detractors. Earl, Watson, Levin, Leithwood, Fullan and Torrence (2003) termed the 1960 s and early 1970 s the era of "uninformed professionalism". A series of five "Black Papers", written by right-wing educationalists and published between 1969 and 1977, attack what the authors saw as the excess of progressive education and indiscipline in schools. The William Tyndale affair of 1975, when radically child-centred methods were introduced by the William Tyndale Junior School's headteacher, resulting in protests against the methods by parents and staff, prompted the press to distribute rumours of anarchy in the English education system. As a result, in 1976, the Labour Prime Minister James Callaghan launched his "Big Debate" on education in a speech given at Oxford University's Ruskin College. This was the beginning of the end for teacher and teacher educator autonomy in England (and Wales). In the 1970s, Kemmis's (2010) views on teachers' individual personalities and pedagogy being socially, discursively, culturally and historically influenced by external values and norms became dominated by neoliberal emphases on teacher education ensuring "professional" conditioned compliance. This approach did not - and still does not - encourage democratic practice.

At the same time, there was an international focus on achievement in language and mathematics, raising concerns about teaching and learning methods in these subjects. In the UK, particular emphasis was placed on identifying the causes of what was perceived as a "long tail of under-achievement" 
in basic literacy and mathematical skills. Stenhouse continued to publicise his belief that it is not politicians, but "teachers who, in the end, will change the world of school by understanding it" (1981, p. 46) and that teacher professionalism should be developed by involvement in studying the work of teaching and actively teaching it, not passively leaving it to university academics. UK Departments of Education were nonetheless given the task of determining the causes of under-achievement in basic literacy and mathematics. The research they produced was, however, widely criticised, particularly in terms of its credibility and usefulness (Hillage, Pearson, Anderson, \& Tampkin, 1998). Foremost amongst the critics was the renowned British educationalist Professor David Hargreaves. Hargreaves had been evaluating the quality of educational research produced by academics in universities at the time, and had identified not only a lack of rigour, but also a dearth of originality and a lack of dissemination of findings in order to inform and develop teachers' practice. He suggested that there was an "urgent need for better professional knowledge about the management of schools and effective teaching and learning" (Hargreaves, 1999, p. 122). He continued by remarking that "One alternative is to treat practitioners themselves as the main (but not only) source for the creation of professional knowledge" (1999, p. 125). Stenhouse, Hargreaves and others proposed that teachers should be the subjects and users of educational research, and should generate educational knowledge on teaching and learning for a wider public audience. Furthermore, they maintained that involvement in research would restore a sense of democratic professionalism and power in teachers, in the sense of having a "voice" and being able to act through informed and evaluated choice.

However, politicians neither listened to their voice, nor recognised their choice. At the DfE, Margaret Thatcher's Education Act signalled the end of university control of education. Theory in teaching, the key to pedagogical development and praxis, was not so much neglected as banished following a right-wing campaign against the belief that teaching required theoretical underpinning. With the Education Reform Act of 1988 prescribing the curriculum, and the 1994 Education Act establishing the Teacher Training Agency to control teacher-training supply, funding and content, teacher and school education became manifestations of government ideology. According to Ball (2003, p. 216), "performativity is a technology, culture and mode of regulation that employs judgments, comparisons and displays as means of incentive, control, attrition and change...[representing] the worth, quality or value of an individual or organisation". Levels of performativity were overseen and maintained by a new regulatory body, the Office of Standards in Education (OfSTED). The quality assurance/audit-driven approach established by Thatcher of prescribed curricula and assessment, league 
tables and inspection of schools and teacher training providers was not tempered by the ascendency of the Labour Party in 1997. Tony Blair's rhetoric of putting emphasis on education and of "raising the bar and closing the gap" was researched by Thompson, Hall and Jones (2010) during the final year of his government. They concluded their research by stating:

We showed that the policy mantra of raising the bar AND closing the gap is an ideological construct which sutures together these two goals in conceived policy space, then mandates a technology of targets and tests. This translates into everyday educational practices geared to the transmogrification of students into data, and their teachers into alchemists, in the perceived space of contemporary English schooling. (2010, p. 653)

The deprofessionalisation of teaching resulted in performance management, increased monitoring and appraisal systems, and curricula prescription tied to testing. This did not provide environments in which the OECD's criterion of supporting teachers in conducting classroom-based individual or collaborative research was easy to establish. Managed by hierarchical administrators, teacher autonomy and responsibility had been replaced by standardisation of work practices and accountability.

Professor David Hargreaves was, however, held in high regard by Blair's government. His influence was such that the Teacher Training Agency, the Department for Education and Skills, and the National Union of Teachers produced initiatives that included the establishment of Best Practice Research Scholarships (BPRS) for teachers' CPD. According to Furlong and Salisbury (2005), during the years 2000-2003, approximately 1,000 scholarships worth up to 3,000 British pounds each were awarded to practising schoolteachers to take part in university-mentored classroom-focused action research. The stipulated approach of action research when applied to education is concerned with critical praxis and its impact on pedagogical practice. It involves "changing individuals on the one hand and on the other, the culture of the groups, institutions and societies to which they belong" (Kemmis \& McTaggart, 1992, p. 16). Furthermore, action research is "a form of collective self-reflective inquiry undertaken by participants in social situations in order to improve the rationality and justice of their own social or educational practices" (Kemmis \& McTaggart, 1992, p. 5). This clearly resonates with the OECD's conclusions from their TALIS work that teacher professionalism is based on autonomy and engagement with peers in order to stimulate positive change.

When the BPRS scheme came to an end in 2003, Furlong and Salisbury's 
(2005) evaluation of its last year revealed both positive and negative results. Their evaluation was based on case studies in 20 schools and an examination of the aims, purposes and methodologies of 100 research proposals. Furlong and Salisbury's findings were that the principle purpose of teacher research was not to contribute to the public stock of knowledge, as is the case for academic researchers, but to improve the pedagogy of the teachers' schools. This is, in fact, what Stenhouse, Hargreaves and others had maintained was the purpose of teacher research back in the 1990s. Indeed, Furlong and Stirling discovered that engagement with the research process, primarily undertaken as action research projects, had a significant impact on participants' CPD in terms of their understanding of what, how and why practice impacted on their teaching, their pupils' learning, parents' perceptions of their schools, and their colleagues' practice. This reflects Kemmis and McTaggart's (1998) argument on the purpose of action research projects in education. However, Furlong and Stirling found that in only a small number of projects were the research methods, methodology and data analysis considered to be robust in terms of academic research.

Despite the end of the BPRS scheme in 2003, practising teachers are still being introduced to research through Masters in Education programmes (Raiker, 2011). Unlike in many countries in Europe, achieving a master's degree is not related to initial teacher education (ITE) and qualified teacher status. Before enrolling in a master's course, teachers are expected to have experience of teaching and learning, and to understand what teacher professionalism means in terms of norms, values and government inspection through OfSTED. However, although most teachers are not involved in 180 credit master's degrees and their associated research, special educational needs and disability (SEND) teachers are required to study two 30-credit units focused on SEND aims, objectives and practice in order to be appointed to SEND roles. An issue now for any teacher engaging in master's courses is that the profession is more time-consuming than it was in the days of the BPRS and similar initiatives. To undertake a master's course involves reading widely about other professionals' research and practice, understanding that social, cultural, political and historical contexts underpin the complexity of educational theory, and being aware of the need to discuss, reflect, critically analyse and evaluate (Raiker, 2010a). Above all, teachers understand that it means the necessity for communicative action arising out of the knowledge and understanding gained, taking place in the public sphere of their schools. In England, Masters in Education courses - and not ITE courses - have the key role in the development of teachers as researchers. This is confirmed by a DfE research report (2017) that states that the few teachers who were confident in carrying out their own research and 
introducing its findings into their practice had undertaken higher level academic study. This suggests that if students' attainment in schools and education faculties rises without emphasising research in ITE, then education curricula must include an alternative element (or elements) that relates to pedagogy and praxis and increases the quality of teachers' professionalism.

There must, however, be teachers who engage with research. Both primary and secondary research involve raising knowledge and understanding beyond individual thought and experience. As Cohen, Manion and Morrison (2005) maintain, it is important that educators have an understanding of the world, of the purposes of this understanding, and of how citizens' worlds are viewed in relation to education. This provides insight into theory and philosophy. Master's students have to undertake a dissertation that requires primary as well as secondary research. It is here, in the dissertation process, that they become teacher researchers with the express aim of improving not only their own practice, but the practice throughout their schools, and it is here that teacher educators' lack of knowledge and practice in educational research can result in students becoming confused, losing direction and failing to achieve their potential. Research by the author (Raiker, 2010b) into the dissertation process identified, amongst other findings, that supervisors' knowledge and practice of the educational research process - in other words, their personal experience in carrying out educational research themselves and writing academically about it - had a direct impact on both the confidence of their students to carry out primary and secondary research, and their dissertation grades. Teacher educators need to be researchers in the field of education so that they have the appropriate understandings of the social, cultural, political and historical influences on teacher identity, professionalism and pedagogy to impart to their students through discursive teaching.

\section{The rise of critical reflection in teacher education}

Despite the difficulties limiting trainees and teachers engaging with research due to government policies and their growing control over teacher and school education, thus curtailing the autonomy of teachers and teacher educators, there has been increasing emphasis on supporting questioning and engaging with dialogic at all levels of education through critical reflection. Questioning to encourage learners to give voice to their thinking was identified as a key finding of research carried out by Clarke, McCallum and Lopez-Charles (2001) as well as the work undertaken by the Assessment Reform Group (2003) at the time when the BPRS scheme came to an end. This research, commissioned by 
the Labour Government, was in response to the realisation that by the time a pupil failed a summative assessment, regarded as assessment of learning, it was too late to take action. The purpose of assessment for learning is to raise achievement by identifying issues as early as possible and addressing them through appropriate interventions. It was recognised that rather than produce shadows of themselves, learners constructed their own views of the world based on reasons that would have meaning for them. This constructive view of learning means there is a recognition that pupils in schools and teacher trainees have an understanding of what they do and do not know. They, too, must therefore be brought into the assessment process. As a facet of educating for democracy, the educator and the learner both give feedback on the assessment, with the educator, as a pedagogue, taking the lead on what is required in order to meet the learning objective. It is the learner's responsibility to achieve the learning objective. Both assessment for and of learning are now contained in the Teachers' Standards under the heading Make accurate and productive use of assessment.

This brings to mind the reflection on educational research by Cohen et al. $(2005$, p. 3) that "research is concerned with understanding the world and that is informed by how we view our world(s), what we take understanding to be, and what we see as the purposes of understanding". As is discussed above, however, research involves systematic and controlled data collection, analysis and evaluation. This is where teacher trainees' involvement with reflection takes them to the realm of educational research, identified through the author's research into theoretical perspectives arising through educational practice (Raiker, 2010a). Analysis of 174 trainee records submitted with their dissertations, three two-hour dissertation support sessions, and structured interviews with six trainees and six supervisors revealed that reflection was a key element in the dissertation process. Reflection was identified as thinking about knowledge with or without purpose. Clearly, teachers assessing for learning have a purpose, as do trainees intent on giving dissertations that will pass, not fail! Having perceived this fundamental definition, the author identified and related a further four key academic skills predicated upon reflection:

- $\quad$ analysis: the application of critical, rational, logical and purposeful reflection to deconstructed knowledge;

- $\quad$ evaluation: the making of judgements on the outcomes of critical, rational, logical and purposeful reflection on deconstructed knowledge;

- synthesis: the fusion of outcomes of evaluation into new knowledge, broadening and/or deepening the knowledge base;

- creativity: the unique restructuring of an individual's mental connections 
to gain new insights through the application of reflective skills on subject knowledge and understanding.

It can be argued that reflection through reflective skills connects three key areas of teacher professionalism: knowledge and understanding of a subject, pedagogy, and work experience. If knowledge and understanding of those three areas and of the reflective skills is sufficient, the distinctiveness of pedagogical practice will be revealed in terms of content, context, criticality, complexity and creativity, i.e., originality. This resonates with research practice and is praxis: there is a connection to theory. Reflection has been present in initial teacher education courses in England since the 199os, based on the theoretical work of John Dewey, Donald Schön, Jack Mezerow and others. The aim of reflection courses concerns understanding the role of critical reflection practice in ITE, recognition of reflective practice models, identifying difficulties in ensuring that reflection leads to learning, and the development of strategies to ensure reflection supporting learning development. A common practice involves reflective journal writing, allowing trainees to construct their own understanding of the critical nature of the classroom environment, which is necessary to provide a context for the learning of children and trainees. In order for critical reflection to become part of teachers' practice, it is therefore considered important that teacher trainers and educators are themselves critically reflective practitioners, and that they make reflection an ongoing part of their courses and sessions.

The Teaching Agency (TA), established in 2011 by the Conservative/Liberal Democrat coalition government led by David Cameron and Nick Clegg, has been and still is responsible for ensuring the supply of high-quality teachers and training, and for teacher regulation. The TA considers professional development as consisting of reflective activity designed to improve an individual's attributes, knowledge and understanding, and skills. It supports individual needs and improves professional practice. However, "reflective activity" takes place in an education system controlled by government through imposed standards, inspection and competition stimulated by the publication of league tables. The outcome is that higher education courses for teachers in England, focused on improving professional practice through "reflective activity", become aligned with, and conform to, government neoliberalist ideology. Being a government agency, the TA's role is to encourage improvements through conformity. This does not resonate with improvement construed as the deepening of personal insight into the epistemological and ontological underpinnings of pedagogy, which are the bases of understanding and creativity. 
Nevertheless, there is clearly a connection between research and reflection. It can be argued that all English educators have the knowledge and understanding to autonomously question their pedagogical practice by developing relationships with their students, be they trainees or pupils. This confirms Part 1 of the Teachers' Standards and involves data collection, both quantitative and qualitative, of individual students so that assessment for and of learning can take place - both for that individual as well as for the age and ability ranges in a school and schools - in a faculty for education and faculties. This has resulted in raising the UK and England's positioning in the Programme for International Student Assessment (PISA), which can be regarded as an example of assessment of learning. PISA examines the knowledge of 15 -year-old pupils in reading, mathematics and science, and assesses what they can do with their knowledge. In the 2015 (OECD, 2016) survey of 70 countries, the UK attained the $15^{\text {th }}$ position in science, $21^{\text {st }}$ in reading and $27^{\text {th }}$ in mathematics. In the 2018 (OECD, 2019) survey of 78 countries, the UK had risen to $14^{\text {th }}$ position in science, $14^{\text {th }}$ in reading and $17^{\text {th }}$ in mathematics. Critical reflection appears to have had a positive effect on pupil learning due to its emphasis on assessment for learning.

\section{Conclusions}

As noted above, the English conception of teachers' professional development, as expressed in the Teachers' Standards, does not include the terms "pedagogy" or "theory". The conclusion can be drawn that the TA does not consider knowledge, understanding and creation of theory to promote pedagogical change as being important in improving practice. Due to this approach, the one-year postgraduate course that prospective primary and secondary teachers undertake to achieve QTS contains little theory.

If the DfE wants to take into account the OECD's proposal that education policies should consider "supporting teachers in conducting classroombased individual or collaborative research" (2016, p. 23) in order to achieve an evidence-informed teaching system influenced by robust research evidence, there would need to be fundamental changes in teacher education.

The DfE would need to acknowledge that the one-year postgraduate course is not long enough for meaningful engagement with educational theory. Knowledge and understanding of such theory take time to develop through relating the role of theory to practice, and thus teaching through praxis; this is fundamental to continuing professional development. Furthermore, those who want to become teachers would need to have higher standards to be admitted into teacher training. There needs to be change. At the time of writing, 
however, there are no indications that the decades-old education policy of separating theory and practice, and constructing courses focused on the latter, will alter. This is not because teachers and teacher educators are against theory; as the DfE's research report (2017) reveals, teachers want to know more about research and theory, but are constrained by time, workload, and lack of financial and school leadership support. According to the research data analysis and evaluation, most teachers value research evidence. While some teachers did not see the value of external research, most did. This is due to the value placed on it by senior leaders and, crucially, because of the need for such evidence to be focused on problems and practice. However, the growing number of children and the declining number of teachers in England mean such changes cannot take place at the moment.

The conclusion is, therefore, that the limited inclusion of theory in ITE courses will cause master's, SEND and doctoral programmes to become increasingly important in ensuring the survival and generation of educational theory. This is supported by the fact that recent governments have not given any indication of an intention to reverse the cutting of funding for teacher-as-researcher projects such as the BPRS scheme in the late 1990s and early 200os. BPRS holders worked with university-based academics so that the essential goals of improving knowledge of subject, practice and educational theory, as well as understanding of research methodologies in education, were achieved. There is nothing similar in existence today. The DfE's qualitative research (2017) indicated that teachers and school leaders (particularly those working in SCITTs) are more likely to look towards specialist organisations and academics to carry out research. This is despite BERA's conclusion that in England and in the UK as a whole, teachers' research and their experiences of being involved in carrying out research would result in self-improvement, both for individual educators and their schools. This would be progress towards re-establishing democratic professional development. However, educational theory and research methodology in university Masters in Education courses currently have to deal with students having basic related knowledge, or none at all, due to the lack of theoretical and research content in ITE and school experience. As the DfE research (2017) concludes, teachers' awareness and understanding of educational theory and research methodology is established through SEND, master's and doctoral courses at universities, not by teachers being researchers in schools.

Trainees currently nonetheless engage with critical reflection in their courses. Whereas the number of teachers taking part in SEND, master's and doctoral studies is limited, virtually all teacher trainees learn about critical reflection and act upon it in their school practice. This means that newly qualified 
teachers work individually and collectively towards a sense of agency, thus promoting peer networks, as recommended by the OECD, and encouraging democratic teacher professionalism. It also results in the emergence of explicit tacit knowledge that can encourage practitioners to link their existing knowledge to research and theory in their field. This resonates with the meaning of praxis. Above all, critical reflection impacts on trainees as well as teachers in analysing, evaluating and, if concluded, changing their pedagogies in a variety of contexts, both theoretically and in practice. This is praxis in action. As discussed above, the UK's positioning in PISA assessments is improving. Critical reflection is working. The quality of teacher professionalism is therefore increasing for the majority of practitioners. As with educational research, critical reflection can be regarded as an aspect of individual teachers' professionalism and their pedagogical understanding. This meets the OECD's criterion for teacher professionalism that knowledge bases containing the necessary information for teaching (including pre-service and in-service training) should involve autonomy in practitioners' work decision-making.

The overall conclusion on this assessment of the importance of research in teacher education being necessary in order for teachers to know about and understand pedagogy and praxis so as to maintain high-quality teacher professionalism, is that this is the case. However, although the encouragement of integrating educational theory and research methodology into ITE is not currently possible, progressing praxis through pedagogical practice via critical reflection is having a positive effect on pupil achievement. Stenhouse and Hargreaves would approve of critical reflection in the current English education system, as it enables teacher professionalism to become more autonomous and thus democratic through a sentient social commitment of teachers to the greater good of their vocation.

\section{References}

Assessment Reform Group. (2003). Working inside the black box. https://www.nuffieldfoundation. org/project/the-assessment-reform-group

Ball, S. (2003). The teacher's soul and the terrors of performability. Journal of Education Policy, 18(2), $215-228$.

Bramwell, R. D. (1976). A humanities curriculum project in English secondary schools. Curriculum

Theory Network, 5(4), 316-322.

BERA [British Education Research Association]. (2014). Research and the teaching profession:

Building the capacity for a self-improving education system. https://www.thersa.org/globalassets/pdfs/ bera-rsa-research-teaching-profession-full-report-for-web-2.pdf 
Carr, W., \& Kemmis, S. (1986). Becoming critical: Education knowledge and action research. Deakin University Press.

Clarke, S., McCallum, B., \& Lopez-Charles, G. (2001). Gillingham partnership formative assessment project 2000-2001. Interim report on the first term of the project: Communicating learning intentions, developing success criteria and pupil self-evaluation. University of London Institute of Education. Cohen, L., Manion, L., \& Morrison, K. (2005). Research methods in education. Routledge Falmer. CHE [Committee on Higher Education]. (1963). Higher education: Report of the committee appointed by the prime minister under the chairmanship of Lord Robbins 1961-63. HMSO

Department of Education and Science. (1988). Education Reform Act 1988. http://www.legislation.gov. uk/ukpga/1988/40/contents

Department for Education. (1994). Education Act 1994. http://www.legislation.gov.uk/ukpga/1994/30/ contents

Department for Education. (2012). Teachers'Standards. https://www.gov.uk/government/ publications/teachers-standards

Department for Education. (2017). Evidence-informed teaching: An evaluation of progress in England. https://assets.publishing.service.gov.uk/government/uploads/system/uploads/attachment_data/ file/625007/Evidence-informed_teaching_-_an_evaluation_of_progress_in_England.pdf Earl, L., Watson, N., Levin, B., Leithwood, K., Fullan, M., \& Torrence, N. (2003). Final report of the external evaluation of England's national numeracy and literacy strategies. Final report. Watching and learning 3. Department for Education and Science.

Department for Education. (2002). Education Act 2002. https://www.legislation.gov.uk/ ukpga/2002/32/contents

Furlong, J., \& Salisbury, J. (2005). Best practice research scholarships: An evaluation. Research Papers in Education, 20(1), 45-83.

Habermas, J. (1986). The theory of communicative action. Polity Press.

Hargreaves, D. H. (1999). The knowledge creating school. British Journal of Educational Studies, 47(2), 122-144.

Hillage, J., Pearson, R., Anderson, A., \& Tampkin, P. (1998). Excellence in research on schools. Her Majesty's Stationary Office.

Hopkins, N. (2020). Teacher education and the development of democratic education in England. In A. Raiker, M. Rautiainen, \& B. Saqipi (Eds.), Teacher education and the development of democratic citizenship in Europe. Routledge.

Kemmis, S. (2010). What is professional practice? Recognising and respecting diversity in understandings of practice. In C. Kanes (Ed.), Elaborating professionalism. Innovation and change in professional practice. Springer Science+Media.

Kemmis, S., \& McTaggart, R. (Eds.) (1992). The action research planner (3rd ed.). Deakin University Press. OECD [Organisation for Economic Co-operation and Development]. (2016). Supporting teacher professionalism: Insights from TALIS 2013. http://www.oecd.org/education/supporting-teacherprofessionalism-9789264248601-en.htm 
OECD [Organisation for Economic Co-operation and Development]. (2016). PISA 2015 results. http://www.oecd.org/pisa/pisa-2015-results-in-focus.pdf OECD [Organisation for Economic Co-operation and Development]. (2019). PISA 2018 results (Volume 1). http://www.oecd-library.org

Raiker, A. (2010a). Creativity and reflection: Some theoretical perspectives arising from practice. In C. Nygaard, C. Holtham, \& N. Courtney (Eds.), Teaching creativity: Creativity in teaching. Copenhagen Business School Press.

Raiker, A. (2010b). An investigation into the undergraduate tutorial as a Personal Development Planning (PDP) process to support learner development. Journal of Learner Development in Higher Education. https://journal.aldinhe.ac.uk/index.php/jldhe/article/view/102

Raiker, A. (2011). Developing a framework for postgraduate education. In C. Nygaard, C. Courtney, \& Liezel Frick (Eds.), Postgraduate education: Form and function. Libri Publishing.

Sibieta, L. (2020). Teacher shortages in England: Analysis and pay options. Education Policy Institute. Simon, B. (1981). Why no pedagogy in England? In B. Simon \& W. Taylor (Eds.), Education in the eighties: The central issues. Batsford.

Stenhouse, L. (1981). What counts as research? British Journal of Educational Studies, 29(2), 23-31. Thompson, P., Hall, C., \& Jones, K. (2010). Maggie’s day: A small scale analysis of English education policy. Journal of Education Policy, 25(5), 639-656.

UCAS [Universities and Colleges Admission Services]. (2019). Update on unconditional offer-making for 2019. https://www.ucas.com/corporate/news-and-key-documents/news/update-unconditionaloffer-making-2019

\section{Biographical note}

Andrea Raiker, PhD, is a Consultant in Higher Education Teaching and Learning in the UK. Her research interests include linguistics and learning, assessment of digital information and events on learning, research in teacher education, and teacher education and the development of democratic citizenship in Europe. 